\title{
Earnings Management in Spain. Some Evidence from Companies Quoted in the Spanish Stock Exchange
}

\author{
Oriol Amat, Jordi Perramon and Ester Oliveras \\ Universitat Pompeu Fabra (Barcelona) \\ Address for correspondence: \\ Universitat Pompeu Fabra \\ Departament d'Economia i Empresa \\ Ramon Trias Fargas, 25 \\ 08005 Barcelona (Spain) \\ email: oriol.amat@econ.upf.es
}

\begin{abstract}
After the accounting scandals that have taken place mainly in the United States during the last years, some Spanish leading authorities have defended the idea that this kind of accounting problems cannot happen in Spain. They argue that accounting regulation in Europe, and specifically in Spain, make more difficult the use of creative accounting practices.

The objective of this paper is to identify some evidence about the situacion in Spain. The study tries to demonstrate that some accounting practices of several of the companies quoted in the Spanish Stock Exchange could be qualified as earnings management.

To carry out this study, the authors have analysed the accounts of the 35 companies included in the stock market index IBEX 35. This index is calculated with the share prices variations of the most important companies quoted in the Spanish Stock Exchange.
\end{abstract}

Keywords: accounting regulation, creative accounting, earnings management, financial accounting, IAS, Spain, IBEX 35.

JEL Codes: M41 
Earnings management in Spain. Some evidence from companies quoted in the Spanish Stock Exchange ${ }^{1}$

\section{Introduction}

When accounting information arrives to users, mostly shareholders and investors, among other stakeholders, it has already gone through a process that has started with the involvement of company executives and later by the corresponding board of directors. Subsequently, the auditors become involved in asserting the reliability of the accounts according to the current accounting and auditing regulation. In Spain, the quality of this process is supervised by bodies such as ICAC (Instituto de Contabilidad y Auditoría de Cuentas, the Institute of Accounting and Auditing, which is the Spanish accounting and auditing regulatory body), CNMV (Comisión Nacional del Mercado de Valores, the Spanish equivalent of the Seccurities and Exchange Commission) or the Spanish Central Bank, among others. Analysts and rating agencies also become involved and finally, the media, which report their opinion about the situation and perspectives of companies.

This process (see figure 1) can sometimes be negatively biased by various factors that affect the agents involved in the process:

-Company executives and board of directors: The pressure for achieving the expected results is emphasized by situations like the present economic recession, and it is aggravated by the generalization of the incentive system based on stock options. This pressure, together with the deterioration of the ethical standards and the absence of signs of good corporate governance can increase the temptation for creative accounting practices and deceive the auditors, the shareholders and other users of accounting information.

-Accounting regulation and supervision agencies: As it is pointed out below, some accounting standards have limitations. Also, there can be problems related to the supervision of the correct application of existing rules. Often, it is said that these agencies "look away" facing obvious cases of infringement of current norms. For example, a few months ago, the media (Pérez, 2002) commented on the pressure that the Spanish Central Bank has put on one of the leading Spanish banks (BBVA) trying to delay the regularization of depreciated goodwill in order to grant time to other leading Spanish bank (BSCH) which is in a similar situation but undergoing difficulties to get on such a regularization.

-Auditors, analysts and rating agencies, the media: It is possible that auditors and analysts have made mistakes, in some of the accounting scandals, not detecting frauds commited by the company officials. Even so, auditors and analysts have defended themselves saying that they, in fact, had been deceived by the company officials. Among the issues that are being questioned, the one that stands out is the impact that an auditing firm offers both consulting and audit services to the same company. Additionally, the impact that may have on analysts the fact that often they are branches of big financial groups which also offer brokerage activities. For example, in August $23^{\text {rd }} 2001$ an analyst was dismissed from the investment bank BNP Paribas

\footnotetext{
1 This paper is a part of the SEC 2000-1062 Research Project financed by the Spanish Ministry of Science and Technology.
} 
after releasing a negative recommendation about Enron. He was the first analyst to announce a negative analysis of Enron. A few months later, in May $21^{\text {st }} 2002$, Merril Lynch agreed with the public prosecutor of New York to pay a fine of Euros 110 million to avoid a trial on deceiving recommendations to investors. Moreover, Merril Lynch committed to separate the bonusses system of its analysts from the business that they may obtain for the investment bank (Nieto, 2002).

Some comments were heard in relation to the interest of the media in broadcasting low quality information about the reality of companies. Despite this, the economic journalists often complain about the lack of relevant and reliable information that receive from companies. It is clear that auditors nor analysts lead to brankrupcies, but if they fail to notify the problems on time they can harm shareholders and investors considerably.

-Users of accounting information: The users are the ones that suffer the consequences of the problems mentioned. There is another important problem called the expectation gap. This gap refers to what users expect from accountants and auditors which is not the same as what these really offer. Users expect that annual accounts inform the reality of a company in order to take right decisions. Hence, they expect that assets are valued in a similar level than market values. They also require that if the company is facing some problems, auditors and analysts report it early enough.

However, auditors and accountants report the information that has to reflect a true and fair view of the balance sheet and economic situation of the company. But by "true and fair view" accountants and auditors do not mean the reality, but what draws from the application of accounting regulation, even if these are far from reality (Amat and Blake, 2002). Accordingly, they can assert that they reflect the true and fair view of accounts that fail to reproduce most of the intangibles, the valuations in market prices of real estate and that, in addition, can vary according to each country's accounting standards. 


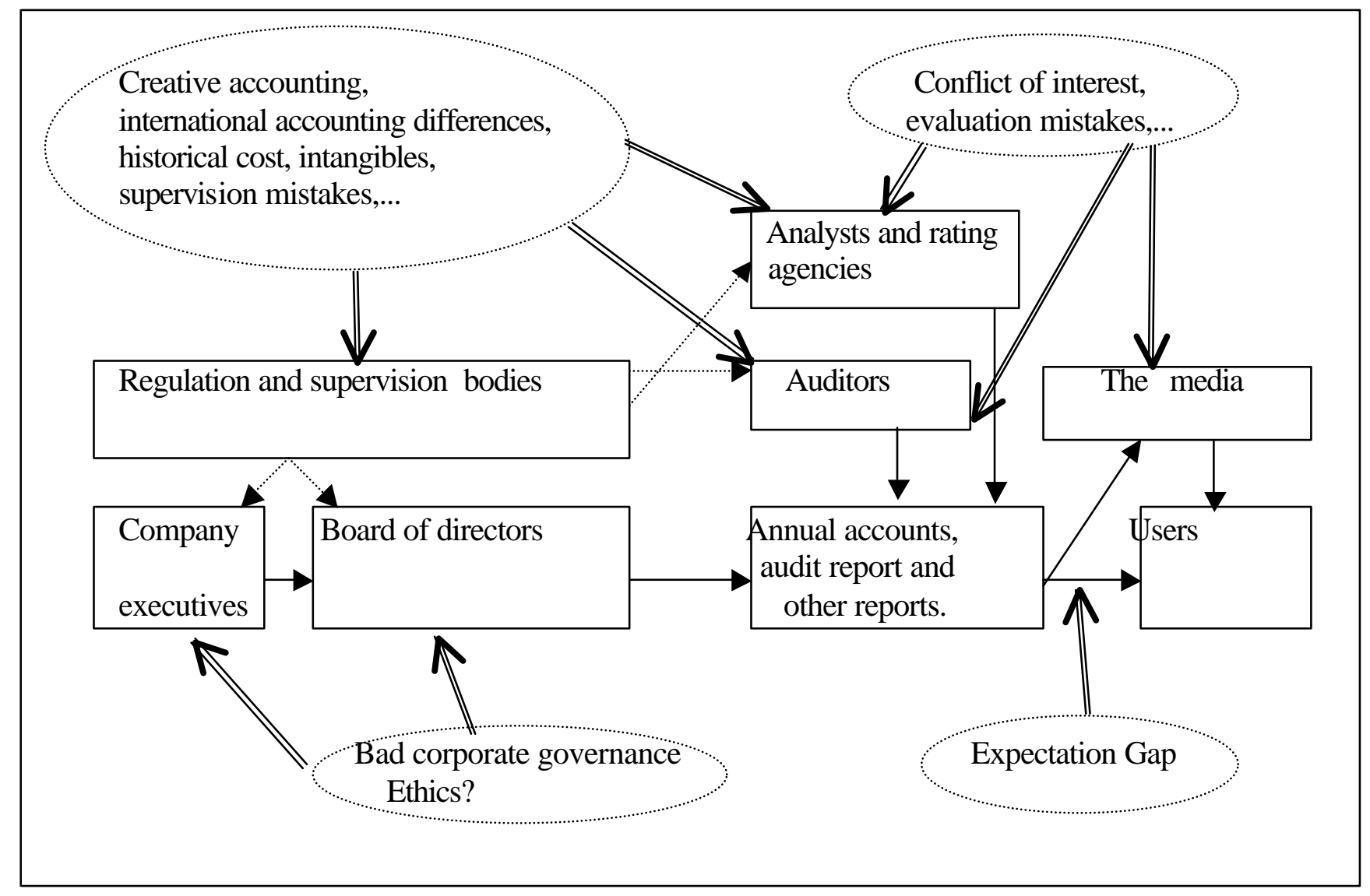

Flow of information

Supervision

Sources of problems

Figure 1. Some of the problems that affect the present crisis in accounting

\section{Some issues of accounting regulation}

There is no doubt that the credibility of the present accounting regulation is being questioned. A recent study by PricewaterhouseCoopers (Dipiazza y Eccles, 2002) shows that only $20 \%$ of the analysts, investors and executives consider that information prepared under the present accounting norms is very useful to know the faithful image of companies. Therefore, according with the study, accounting is deficient from the user's point of view.

Some issues of the Spanish accounting regulation that deserve attention are:

a) Historical cost: The principles of prudence and historical cost indicate that assets must be valued according to the lowest price between the acquisition price and the market price. Also, the acquisition price is reduced by the corresponding accumulated depreciation. These can also increase when assset revaluation laws are approved (the last one was in 1996). The consequence is that assets acquired a long time ago, especially buildings, have an accounting value that is far from the real value. 
b) International accounting differences: As a lot of research has demonstrated, accounting regulation varies considerably from country to country. This explains why the same transaction can have a different impact on accounts depending on the country.

The areas where differences are greater among countries are: the criteria for valuing assets, the handling of revenue and expenses, asset depreciation and provisions, stock options, research and development, the acknowledgement of contingencies, pension plans, foreign currency operations, derivatives, norms of consolidation and the criteria for estimating future transactions, among others.

An interesting example is the one provided by the seven Spanish companies that are quoted in the Spanish Stock Exchange and in the New York Stock Exchange. Important accounting differences were found in the accounts of companies that had to comply with the Spanish accounting regulation as well as the US GAAP. In all the cases, the earnings obtained according to the USA accounting criteria are inferior to the ones calculated under the Spanish standards. Conversely, the same type of comparison carried out two years before presented inverse results. This example (see figure 2) shows the effect that produces handling the goodwill depreciation differently in a year of decreasing stock market values since values in the United States are adjusted according to the market value of subsidiaries, whereas in Spain, goodwill is depreciated in a lineal basis, usually in twenty years.

\begin{tabular}{|l|r|r|}
\hline Company & $\begin{array}{l}\text { Net income under Spanish } \\
\text { accounting rules }\end{array}$ & Net income under US GAAP \\
\hline BBVA & $+2,363$ & +680 \\
\hline Endesa & $+1,479$ & $+1,034$ \\
\hline SCH & $+2,486$ & $+2,176$ \\
\hline Repsol & $+1,025$ & +980 \\
\hline Telefónica & $+2,106$ & $-7,182$ \\
\hline Telefónica Móviles & +893 & +320 \\
\hline Terra & -566 & $-11,411$ \\
\hline Total & $\mathbf{+ 9 , 7 8 6}$ & $\mathbf{- 1 3 , 4 0 3}$ \\
\hline
\end{tabular}

Source: Financial accounts of each company.

Figure 2. Net income of Spanish companies that are traded in the NYSE (data referred to 2001 in million Euros).

These differences hinder the comparison among companies from different countries and also increase the mistrust of the users towards accounting.

c) Intangibles: The basis of present accounting regulation were designed a few centuries ago when tangible assets, such as buildings and inventory, were the most important assets of a company. At the present time in many companies, a large portion of the value is in the intangible assets, such as trademarks, know-how of its employees, distribution network, customers, technology and others. Most of these assets are not included in the accounts, and explains the big difference between the accounting value of a firm and its market value (Lev, 2001). For example, on March $30^{\text {th }} 2002$, the market value in the USA exceeded 4.3 times the accounting value for the values included in the Standard and Poor's Index. In Spain, on August $11^{\text {th }} 2002$ the value was 3.5 times larger that the IBEX35.

d) Earnings management: Another problem in accounting regulation is the wide scope for earnings management, also called creative accounting, practices The objective of earnings management is carried out to make the accounts reflect what is 
in the interest of executives and administrators (Griffiths, 1995). Through this process, the reality can be hidden and users deceived from the accounts.

Earnings management is based on three pillars:

-First, accounting regulation allows that the same transaction may be accounted for in different ways. We are referring mainly to the criteria for asset valuing, the accounting for revenues and expenses, depreciation and provisions, research and development, contingencies, pension plans, foreign currency operations, consolidation, among others. This allows the use of a more conservative or less conservative accounting approach according to specific interests. On the other hand, in some cases, companies can change the accounting criteria used in one year to another. In any case, this change has to be explained in the notes to the accounts and the auditors have to report about it.

-Second, there are many operations that are not fully regulated by accounting norms. In Spain, for example, accounting for stock options, the quantification of debt concerning pensions or some operations with financial instruments.

-Finally, in order to account for certain transactions, optimistic or pessimistic assumptions about the future can be drawn.

The combination of these three pillars explains why companies can manipulate their accounts without stepping outside the accounting regulation. This affects the accounting regulation of every country, including the USA as Largay (2002) points out: "the gaps and flexibility of the US GAAP allow a great variety of accounting results."

In order to examine the impact of using the possibilities offered by the accounting regulation, it can be useful to apply the most conservative and least conservative criteria to a real Spanish company (figure 3). It can be observed that the net earnings figure of this company can fluctuate between -31 to +140 , according to the Spanish regulation. The accounting criteria applied was the most commonly used, the most conservative and the least conservative. These criteria were applied to the transactions that took place during 2000. A base of 100 is considered for the net income of the company according to the most common criteria included in the Spanish accounting regulation. As an example, it has been considered that the average price method is the most common criterion when valuing inventories. Whereas, the most conservative is LIFO, and the least conservative is FIFO, considering that the Spanish accounting regulation accepts all three methods.

\begin{tabular}{|l|l|l|l|}
\hline & $\begin{array}{l}\text { Most common } \\
\text { criteria }\end{array}$ & $\begin{array}{l}\text { Most } \\
\text { conservative } \\
\text { criteria }\end{array}$ & $\begin{array}{l}\text { Least } \\
\text { conservative } \\
\text { criteria }\end{array}$ \\
\hline $\begin{array}{l}\text { Net profit according to the Spanish } \\
\text { accounting regulation }\end{array}$ & 100 & -31 & 140 \\
\hline
\end{tabular}

Source: Own elaboration.

Figure 4. Variations in net income of a company using the most common criteria, the most conservative and the least conservative criteria according to the present Spanish accounting regulation

Another example can be found in Telefónica, according to Muñoz (2002) "the analysts ...demanded a greater effort of realism in the accounts...In the end, there was a green light for the department of finance to provide a more realistic balance of assets of the company, by presenting the 2001 accounts to the SEC, the maximum 
supervising authority of the US markets. This balance presented losses of around 7,182 million euros, after a valuation of 8,452 million euros which included the acknowledgement that Endemol and Lycos were now worth less than a fifth part of what was paid for them at their time".

\section{Detecting earnings management practices}

As mentioned before, an earnings management practice means that a company chooses the most favourable accounting treatment among different aproaches permitted, or takes advantage of an area not fully regulated by accounting rules or makes an optimistic (or pessimistic) assumption about the future.

To discover this kind of practices it is possible to use different approaches.

There are earnings management practices that can be detected in the annual accounts of the company. Therefore, it is convenient to identify the accounting criteria utilized, which is explained in the notes. It is necessary to compare these criteria with those of previous years and those of the competitors. In this way, we can identify the changes of criteria in relation to past years, or identify accounting practices more (or less) conservative than those of the competitors.

Considering that a company quoted in the Spanish Stock Exchange can present the accounts including auditors' qualifications, it is also necessary to review the audit report in case there are any qualifications. Qualifications can be referred to changes of criteria in relation to the previous year or to other contingencies not included in the accounts.

Another technique to use is the analysis of extraordinary results and results of previous years, attempting to hide a variation that is not desired to appear in the ordinary results. The analysis of the evolution of the terms of customers, inventory and suppliers is also recommended, in order to detect manipulations that could affect these accounts (Spathis et al, 2002).

Sometimes, accounts manipulation is done through related companies carrying out fictitious operations at prices different than market prices. Therefore, it is important to analyse the operations with related companies.

Often, creative accounting is done with the pertinent authorizations of the supervising agencies which allow a company to apply rules different than the ones included in the present accounting regulation. These kind of authorizations are given after a lobbying process made by a company or an industry which tryes to take advantage of their power of influence towards the Government. Hence, it is necessary to revise possible authorizations for special cases, because even though being legal they are still creative accounting practices. For example, the Spanish Central Bank has occasionally authorized a bank under difficulties not to apply certain norm regarding provisions for bad loans. During times of currency devaluation, the Spanish accounting regulatory body also authorized certain companies, in the utilities industry for example, to stop applying the norms concerning losses incurred by differences in exchange rate.

There are other accounts manipulations that are not detected by looking at the annual report. In any case, it is essential to revise the accounting books, even though these are revisions that are carried out by the auditors.

Sometimes manipulations can be done without stepping outside the present accounting regulation. For example, in figure 4 there are several techniques (like numbers $1,2,3,4,5,6,7$ and 14) that can be legal. On the other hand, the rest of the techniques in figure 4 are clearly illegal. 
These techniques for detecting account manipulations have to be applied particularly in special occasions like when a company goes public or during changes in the executive team of a company.

\begin{tabular}{|c|c|c|}
\hline Earnings management techniques & Impact on the accounts & $\begin{array}{l}\text { How can they be } \\
\text { detected? }\end{array}$ \\
\hline $\begin{array}{l}\text { 1-Increasing or reducing expenses. Not } \\
\text { recognizing expenses from stock options }\end{array}$ & $\begin{array}{l}\text { Reduction or increase in profits, } \\
\text { equity, assets and debts. }\end{array}$ & $I, I I, I I I, V I I I$ \\
\hline $\begin{array}{l}\text { 2-Considering } R+D \text { to be an expense or } \\
\text { capitalizing } i t^{2} \text {. }\end{array}$ & $\begin{array}{l}\text { Reduction or increase in profits, } \\
\text { equity and assets. }\end{array}$ & $I, I I, I I I$ \\
\hline $\begin{array}{l}\text { 3-Expenses charged to reserves, instead of } \\
\text { including them in the } P \& L \text { account }{ }^{3} \text {. }\end{array}$ & Increase in profits. & $I I I, I V, V I I I, I X$ \\
\hline $\begin{array}{l}\text { 4-Off balance sheet financing through not } \\
\text { consolidated subsidiaries or through } \\
\text { Special Purpose Entities. }\end{array}$ & Debt reduction. & $I V, V I I$ \\
\hline $\begin{array}{l}\text { 5-Changing the criteria for valuing } \\
\text { inventories. }\end{array}$ & $\begin{array}{l}\text { Reduction or increase in profits, } \\
\text { equity and assets. }\end{array}$ & $I, I I, I I I, V I$ \\
\hline $\begin{array}{l}\text { 6-Accounting for transactions making } \\
\text { pessimistic or optimistic estimates about } \\
\text { the future. }\end{array}$ & \begin{tabular}{|l|} 
Increase or reduction in profits, equity \\
and other assets and liabilities.
\end{tabular} & $I, I I, I I I, I V$ \\
\hline $\begin{array}{l}\text { 7-Generating extraordinary results in order } \\
\text { to improve the accounts, or vice versa. }\end{array}$ & $\begin{array}{l}\text { Increase or reduction in profits, equity } \\
\text { and other assets and liabilities. }\end{array}$ & $V$ \\
\hline $\begin{array}{l}\text { 8-Considering the extraordinary results as } \\
\text { ordinary, or vice versa. }\end{array}$ & $\begin{array}{l}\text { Increase or reduction in profits, equity } \\
\text { and other assets and liabilities. }\end{array}$ & $I, I I I, I V, V$ \\
\hline $\begin{array}{l}\text { 9- Anticipating the identification of income } \\
\text { or deflecting the identification of expenses. }\end{array}$ & Increase in profits and equity. & $I, I I, I I I, I V, V I$ \\
\hline $\begin{array}{l}\text { 10-Deflecting the identification of income } \\
\text { or anticipating the identification of } \\
\text { expenses. }\end{array}$ & Reduction in profits and equity. & $I, I I, I I I, I V, V I$ \\
\hline 11-Fictitious sales. & Increase in profits, equity and assets. & $I I, I I I, I V, V I, V I I$ \\
\hline $\begin{array}{l}\text { 12-Compensating asset and liability } \\
\text { accounts as well as income and expenses. }\end{array}$ & \begin{tabular}{|l|} 
Increase or reduction in profits, equity \\
and other assets and liabilities.
\end{tabular} & $I I I, I V$ \\
\hline $\begin{array}{l}\text { 13-Transactions valued at non-market } \\
\text { prices, fake prices or willing to deceive } \\
\text { with firms that are consolidated. }\end{array}$ & \begin{tabular}{|l|} 
Increase or reduction in profits, equity \\
and other assets and liabilities.
\end{tabular} & $I I, I I I, I V, V I, V I I$ \\
\hline $\begin{array}{l}\text { 14-Not providing information about } \\
\text { subsidiaries with the excuse that it has a } \\
\text { high strategic value. }\end{array}$ & $\begin{array}{l}\text { Increase or reduction in profits, equity } \\
\text { and other assets and liabilities. }\end{array}$ & III \\
\hline
\end{tabular}

Note: I (compare with accounting criteria of past years)

II (compare with the competition's accounting criteria and indicators)

III (analyse whether there are any qualifications in the audit report)

IV (examine accounting books)

$\mathrm{V}$ (analyse the extraordinary results and results from previous periods)

VI (analyse the evolution of client, inventories and suppliers periods)

VII (analyse the operations with related firms)

VIII (examine possible authorizations of special treatments)

Figure 4. Some earnings management accounting techniques, impact on the annual accounts and detection methods.

Recently, many Spanish leading authorities have mentioned that the accounting scandals that took place in the United States are unlikely to happen in Spain. In spite of these opinions, the analysis of accounts of the firms that are quoted in the stock exchange shows us a different perspective. For example, reviewing the accounts for

\footnotetext{
${ }^{2}$ In Spain, $\mathrm{R}+\mathrm{D}$ can be capitalized under several circumstances.

${ }^{3}$ This can be done if the company gets an special authorization by regulating or supervising bodies.

${ }^{4}$ This practice is possible according to Spanish accounting regulation.
} 
2001 Jimenez and Abril (2002) stated in relation to companies included in the IBEX 35 index and other big listed companies:

- There are firms that should declare less benefits if they accounted the existing risks, specifically derived from the Latin-American crisis (for example, Telefónica, Telefónica Móviles, Repsol, Aguas de Barcelona and Aurea), due to fiscal contingencies (for example, Koipe, Natra, Quijano, Tafisa, Vidrala, Urbas and Aforasa) or due to expenses charged to reserves (for example, BBVA and BSCH).

-There are firms that show positive net earnings when they are in fact incurring losses (for example, Sol Meliá and Campofrio).

-There are firms that should declare even more losses (for example, Picking Pack and Tafisa).

-There are firms that declare extraordinary profits as operating results (for example, Unión Fenosa).

- There are firms that have not provided the required information to the auditors (for example, Pescanova, EADS, Avanzit, Funespaña and Urbas).

From the previous information, it seems that there is a significant number of firms with accounting problems according to Jimenez and Abril (2002).

\section{Empirical study}

\subsection{Research method and sample}

In order to identify the existence and importance of earnings management practices we have studied the annual accounts including the auditors' reports for the year 2001. The following findings have been considered as possible indicators of earnings management practices:

-Changes of accounting criteria from one year to the other. These changes need to be explained and quantified by the auditors in their reports.

-Other auditors qualifications included in their reports.

-Special authorizations in order to apply accounting treatments not included in the present accounting regulation. Usually, these authorizations are explained in the notes.

-Existence of extraordinary results and results of previous years in the profit and loss account of the year.

We have chosen the 35 companies included in the IBEX 35 index for several reasons. First, these are companies listed in the Spanish Stock Exchange which implies that are companies that need to meet more complete and strict controlling rules issued by the Government and stock exchange supervisory bodies. Second, these companies are the biggest among the more than five hundred companies listed in the Spanish Stock Exchange. Third, because of the previous reasons it could be assumed that these companies have more reliable corporate governance controls in comparison to other firms.

\subsection{Results}


First, we have analysed the qualifications from auditors and special authorizations for accounting treatments not included in the present regulation (see figure 5). With this information we have calculated the adjusted net earnings. The data shows that 8 out of 35 companies (22\% of the companies) have auditors qualifications and/or authorizations for special accounting treatments. The impact of these adjustments represents $27 \%$ of the total net earnings of the 8 companies that have this kind of adjustments and $10 \%$ of the total net earnings of the IBEX 35 companies. These percentages are higher ( $30 \%$ and $15 \%$, respectively) if we consider the individual accounts of each company (see figure 6).

The following are the most common practices affecting earnings that were found while examining the audit reports:

-Expenses (goodwill depreciation or reestructuring plans, for example) charged against reserves, instead of including them in the profit and loss account.

-Insufficient provisions (bad debts or the crisis in Argentina, for example).

-Reduction of earnings due to future losses.

Second, we have analysed the extraordinary results. In figures 5 and 6 we have not included extraordinary items although they can be in some cases indicators of earnings management practices of the firms. The weight of extraordinary results is also important in IBEX 35 companies because in 2001 the extraordinary profits amounted 8.417 million euros and extraordinary losses amounted 9.299 million euros, which represented $54 \%$ and $60 \%$, respectively, of the consolidated total net earnings (15.467 million euros):

Total net earnings

Extraordinary profits

15.467 million euros

Extraordinary losses

-8.417 million euros $(54 \%)$

+9.299 million euros $(60 \%)$

Net earnings before extraordinary results 16.349 million euros

Third, we have analysed the notes to the financial statements. A number of practices that may be qualified as earnings management have been observed:

-Expenses (risk provisions, pension plans, taxes) charged to reserves instead of including them in the profit and loss account.

-Insufficient provisions.

-Expense capitalization.

-Changing the inventory valuation system.

-Accelerating depreciation.

-Extraordinary fees for pension plans.

-Not reflecting expenses entailed by stock options. 


\begin{tabular}{|c|c|c|c|c|c|}
\hline Company & \begin{tabular}{|l} 
Net \\
earnings \\
(million \\
euros) \\
(a) \\
\end{tabular} & $\begin{array}{l}\text { Auditors } \\
\text { qualifications } \\
\text { (million } \\
\text { euros) } \\
\text { (b) } \\
\end{array}$ & \begin{tabular}{|l} 
Special \\
authorizations \\
(million euros) \\
(c)
\end{tabular} & \begin{tabular}{|l|}
$\begin{array}{l}\text { Adjusted net } \\
\text { earnings } \\
(\text { million euros }) \\
(d)=a+b+c\end{array}$ \\
\end{tabular} & $\begin{array}{l}\% \text { of increase }(+) \\
\text { or reduction } \theta) \text { in } \\
\text { net earnings } \\
(e)=(d-a) / a \times 100\end{array}$ \\
\hline Acciona & 138 & -67 & 0 & 71 & $-48 \%$ \\
\hline BBVA & 2363 & +64 & -479 & 1948 & $-18 \%$ \\
\hline $\mathrm{BSCH}$ & 2486 & 0 & -696 & 1790 & $-28 \%$ \\
\hline FCC & 241 & 8 & 0 & 249 & $+3 \%$ \\
\hline Gamesa & 62 & -11 & 0 & 51 & $-18 \%$ \\
\hline Popular & 565 & 0 & -99 & 466 & $-17 \%$ \\
\hline Prisa & 77 & +21 & 0 & 98 & $+27 \%$ \\
\hline Sol Meliá & 59 & -363 & 0 & -304 & $-415 \%$ \\
\hline Subtotal & 5991 & -355 & -1274 & 4362 & $-27 \%$ \\
\hline $\begin{array}{l}\text { Other IBEX } \\
35 \text { companies }\end{array}$ & 9476 & 0 & 0 & 9476 & $0 \%$ \\
\hline Total & 15467 & -355 & -1274 & 13838 & $-10 \%$ \\
\hline
\end{tabular}

Figure 5. Auditors qualifications, special authorizations and adjusted net earnings of IBEX 35 companies using consolidated accounts (year 2001)

\begin{tabular}{|c|c|c|c|c|c|}
\hline Company & $\begin{array}{l}\text { Net } \\
\text { earnings } \\
\text { (million } \\
\text { euros) } \\
\text { (a) }\end{array}$ & $\begin{array}{l}\text { Auditors } \\
\text { qualifications } \\
\text { (million } \\
\text { euros) } \\
\text { (b) }\end{array}$ & \begin{tabular}{|l|} 
Special \\
authorizations \\
(million euros) \\
(c)
\end{tabular} & \begin{tabular}{|l} 
Adjusted \\
net \\
earnings \\
(million euros) \\
$(\mathrm{d})=\mathbf{a}+\mathbf{b}+\mathbf{c}$
\end{tabular} & $\begin{array}{l}\% \text { of } \\
\text { increase }(+) \\
\text { or reduction } \\
(-) \text { in } \\
\text { net earnings } \\
(\text { e) }=(\text { d-a }) / \mathbf{a} \times \\
100\end{array}$ \\
\hline Acciona & 65 & -60 & 0 & 5 & $-92 \%$ \\
\hline Altadis & 207 & -11 & 0 & 196 & $-5 \%$ \\
\hline BBVA & 1312 & 0 & -472 & 840 & $-36 \%$ \\
\hline $\mathrm{BSCH}$ & 1330 & 0 & -417 & 913 & $-31 \%$ \\
\hline Gamesa & 7 & -11 & 0 & -4 & $-157 \%$ \\
\hline Popular & 447 & 0 & -59 & 388 & $-13 \%$ \\
\hline Subtotal & 3368 & -82 & -948 & 2338 & $-30 \%$ \\
\hline $\begin{array}{l}\text { Other IBEX } \\
35 \text { companies }\end{array}$ & 3622 & 0 & 0 & 3622 & $0 \%$ \\
\hline Total & 6990 & -82 & -948 & 5960 & $-15 \%$ \\
\hline
\end{tabular}

Figure 6. Auditors qualifications, special authorizations and adjusted net earnings of IBEX 35 companies using individual accounts (year 2001)

The joint analysis of the auditors reports and the notes can be summarized in figure 7 . The percentage of increase or reduction of earnings has been calculated quantifying the qualifications included by the auditors in the audit report and the impact of the practices explained in the notes to the financial statements that can be considered as earnings management.

As indicated before, most of the related practices can be legal, although they alter earnings and the image shown by the financial statements.

Analysing the auditors qualifications and the notes in the financial accounts of 1999, 2000 and 2001 of the firms included in the IBEX-35 index we have found some evidence that several companies have done some kind of profit smoothing (see figure 7): 
-It can be observed that in 1999, a year with a positive economic environment, the predominant firms where those which whithout earnings management practices would have increased their earnings ( 9 firms would have increased their earnings while 5 firms would have reduced them).

-Instead, in 2001, when the economic situation was in a clear recession, there were more firms that would have reduced their earnings (10 firms would have reduced would their results while 3 firms would have increased them).

\begin{tabular}{|c|c|c|c|}
\hline Company & 1999 & 2000 & 2001 \\
\hline Acciona & & & $-92 \%$ \\
\hline Acerinox & $+3 \%$ & $+1 \%$ & \\
\hline Alba & $+5 \%$ & $+2 \%$ & \\
\hline Altadis & & & $-5 \%$ \\
\hline Acesa & $-3 \%$ & $-3 \%$ & \\
\hline BBVA & $-14 \%$ & $-58 \%$ & $-39 \%$ \\
\hline $\mathrm{BSCH}$ & $-74 \%$ & $-44 \%$ & $-33 \%$ \\
\hline Bankinter & $+2 \%$ & & $+2 \%$ \\
\hline Carrefour & $+11 \%$ & $+7 \%$ & +6 \\
\hline Dragados & $+13 \%$ & $-10 \%$ & $+10 \%$ \\
\hline Endesa & $+2 \%$ & $-219 \%$ & \\
\hline Gamesa & & $-952 \%$ & $-157 \%$ \\
\hline Gas Natural & & & $-1 \%$ \\
\hline Iberdrola & $-21 \%$ & $-74 \%$ & \\
\hline Indra & $+3 \%$ & $+9 \%$ & \\
\hline Popular & & & $-10 \%$ \\
\hline Prisa & & $+14 \%$ & \\
\hline Red Eléctrica & $-2 \%$ & $-3 \%$ & $-5 \%$ \\
\hline Sogecable & & & $-2.511 \%$ \\
\hline Sol Meliá & & $-73 \%$ & $-116 \%$ \\
\hline Telepizza & & $-252 \%$ & \\
\hline Telefónica & $+10 \%$ & & \\
\hline Unión Fenosa & $+37 \%$ & $-15 \%$ & \\
\hline
\end{tabular}

Figure 7. Percentages of differences between published net earnings and adjusted net earnings after auditors qualifications, special authorizations and other earnings management practices observed in the notes of IBEX 35 companies using individual accounts (years 1999, 2000 and 2001)

It is important to note that all the practices observed, which can be considered as earnings management, can be identified through the published annual accounts of the companies. What is not clear is if the users of the financial accounts are able to identify them and have the time to do it. It has been observed that the analysts' reports in Spain usually fail to mention when a company has auditors qualifications, special treatments or other indicators of earnings management practices.

\section{$\underline{\text { 5.Conclusions, limitations and directions for future research }}$}

Users expect that the accounts will provide reliable, objective and relevant information that can be comparable to other firms at the national and international level. However, drawn from the previous analysis, it seems that earnings management is implemented in some companies, favoured by the current regulation. This may harm the reliability of accounting information.

Profound changes in the accounting regulation and its supervision are required to fulfil the user's expectations. 
The possibilities for earnings management must be reduced. Therefore, regulators must eliminate from the accounting standards the alternatives that allow different treatments for the same transaction. This may reduce the margin for earnings management.

Considering than in a few years many countries, including Spain, are going to adapt their regulation to the International Accounting Standards it is necessary that the IASB reduce the number of different treatments allowed. Each transaction should be accounted in just one way in order to reduce the possibilities of earnings management.

It is crucial that companies listed in stock exchanges are forced to introduce in their accounts the qualifications from the auditors, when these can be quantified. As it has been explained this is not the case now in Spain.

On the other hand, it is not enough to improve the norms. It is vital that the supervising agencies and the judicial system guarantee the execution of the present legislation. In this sense, we can be optimistic since the Spanish accounting regulatory body as well as other agencies have already adopted a positive attitude regarding reforms in the accounting regulation and towards a more accurate supervision.

Finally, while all these recomendations are not implemented it would be desirable that analysts include the information concerning earnings management practices in their reports in order to help investors to take better decisions.

This study has some limitations. Among them it should be mentioned that we have considered only earnings management practices, which can be identified easily through the published accounts. Recent cases like Enron, WorldCom, Xerox and Ahold, for example, suggest that the main important accounts manipulations could not have been detected without having access to information that was not available in the published financial accounts. Another limitation is that IBEX 35 companies are not representative of the business environment of Spain. On one hand they have more controls and corporate governance guidelines but on the other hand they may have more pressure from the markets in order to meet analyst's expectations.

Our results suggest opportunities for further research. First, this kind of study could be applied to a different sample of companies in order to identify what happens with companies not so big and with companies that are not listed in a stock exchange. Second, the study could be applied to more years to analyse the earnings management evolution in a longer trend. Third, a broader definition of creative accounting practices could be used in order to have a more complete view of the problem. 


\section{References}

ACCID (2003): "Comprender las Normas Internacionales de Contabilidad”, Gestión 2000, Barcelona. AECA (1999): "Marco conceptual para la información financiera", Asociación Española de Contabilidad y Administración de Empresas, Madrid.

Amat, O. (2003): "Problemas de la información financiera: ¿Son las Normas Internacionales de Contabilidad la solución?, en "La empresa española en el siglo XXI, Revista del Instituto de Estudios Económicos, num. 1-2003.

DiPiazza, S.A. y Eccles, R.G. (2002): "Building public trust. The future of corporate reporting", Wiley, New York.

Eccles, R.G., Herz, R.H, Keegan, E.M. y Phillips, D.M.H. (2001): “La revolución Value Reporting", Deusto, Bilbao.

Griffiths, I. (1995): “New creative accounting”, MacMillan, London.

IASC (2000): "International Accounting Standards explained", International Accounting Standards Committee, London.

ICAC (2002): "Informe sobre la situación actual de la contabilidad y líneas básicas para abordar su reforma", Instituto de Contabilidad y Auditoría de Cuentas, Madrid.

Jiménez, M. y Abril, I., "El auditor pone pegas a las cuentas de 2001 de una de cada cuatro empresas cotizadas", CincoDías, July $4^{\text {th }} 2002$, page 2.

Jiménez, M. y Abril, I. (2002): "Cuentas a la americana", CincoDías, June $13^{\text {th }}$, page 4.

Largay, J. (2002): "Lessons from Enron”, Accounting Horizons, volume 16, num. 2, page 154

Lev, B. (2001): "Intangibles: Management, Measurement and Reporting", Brookings Institution Press, New York.

Low, J. y Cohen, P. (2002): "Invisible advantage. How intangibles are driving business performance", Perseus Publishing, Cambridge.

Martinez, R. (2002): “Cerco a los auditores”, El País, Suplemento Negocios, July $7^{\text {th }}$, page 5.

McBarnet, D. And Whelan, C. (1999): "Creative accounting and the cross eyed javelin thrower", Wiley, Chichester.

Miller, P. (2002): “Quality financial reporting”, McGraw Hill, New York.

Mohrle, S.R. (2002): "Do firms use restructuring charge reversals to meet earnings targets?", The Accounting Review, vol. 77, num. 2, pages 397-423.

Mulford, Ch.W. y Comiskey, E.E. (2002): "The financial numbers game. Detecting creative accounting practices", Wilew, New York.

Muñoz, R. (2002): “Telefónica se pone a la defensiva”, El País, July 28th, page 5.

Nieto, A.B. (2002): "Los inversores presentan demandas para ser indemnizados", CincoDías, May 22nd, page 29.

Penman, S.H. y Zhang, X. (2002): "Accounting conservatism, the quality of earnings, and stock returns", The Accounting Review, vol. 77, num. 2, pages 237-264.

Pérez, e. (2002): "Caruana pide al BBVA que retrase el saneamiento para dar tiempo al SCH", La Vanguardia, September $25^{\text {th }} 2002$.

Proyecto MERITUM (2002): "Directrices para la gestión y difusión de la información sobre intangibles. Informe de capital intelectual”, Fundación Airtel-Vodafone, Madrid.

Guidelines of the European Parliament, May $27^{\text {th }} 2002$, relative to the application of international accounting norms.

Spatis, Ch., Doumpos, M. and Zopounidis, C. (2002): "Detecting falsified financial statements: a comparative study using multicriteria analysis and multivariate statistical techniques", European Accounting Review, vol.11, num.3, pages 509-535.

Suozo, P, Sutherland, G, Cooper, S. y Deng, Z. (2002): “Can you trust the numbers?", UBS Warburg, London.

www.ifad.net, GAAP 2001. 